\title{
Employing Persons with Mobility Disability in Travel Agencies: An Exploratory Study Applied to Egyptian Travel Agencies
}

\author{
Mona Abdelbadie EI Moghazy
}

Nashwa Samir El Sheriff

\begin{abstract}
Despite the continuing international concern to promote employment of persons with disabilities, discrimination against them in the global labor market still exists while many workplaces - including tourism - remain inaccessible to them. The present study is considered the first study that explores the perception of travel agents towards employing persons with mobility disabilities. Therefore, it largely contributes to the existing body of knowledge concerning the factors influencing the inclusion of persons with mobility disabilities in the global tourism workplace. In this respect, a measurement scale was developed to assess the perception of travel agents towards employing persons with mobility disabilities. Multiple regression analysis and independent sample t-test were used to assess the effect of the barriers that travel agencies encounter in employing persons with mobility disabilities on their future intentions with regard to recruiting persons with disabilities and to detect significant differences between large and small travel agents in terms of overcoming existing barriers and future intentions. The study findings reveal that the cost barrier is the key barrier that encounters travel agencies to employ persons with mobility disabilities. Tax exemption and country's assistance in the cost of medical insurance were reported as the most important means to encourage travel agents to employ persons with mobility disabilities. Specialized education and training programs and advertisements were found to be the most important means to overcome barriers to employ persons with mobility disabilities in travel agencies. The study indicates that negative appreciation of employers is considered the main barrier that negatively affects the future intentions of travel agents to employ persons with mobility disabilities. There were no significant differences between large and small travel agencies in perceiving potential means of overcoming different barriers to employ persons with mobility disabilities.
\end{abstract}

The research generates insights for managers to assess key barriers that prevent them employing persons with mobility disabilities, potential means 


\section{Employing Persons with Mobility Disability in Travel Agencies: An Exploratory Study Applied to Egyptian Travel Agencies}

that encourage travel agents to employ persons with mobility disabilities and ways to overcome existing barriers based on agents' points of view.

Keywords Tourism, mobility disability, Employment, Workplace, Travel agencies.

\section{Introduction}

Disability is a complex phenomenon that exists at the intersection of human differences and social values, a multifaceted relationship between society and people who function differently from the norm (UIC, 2015) and a key aspect of human experience that intersects with many overlapping disciplines in the humanities, sciences, and social sciences (SDS, 2016). While reliable data on the employment of persons with disabilities worldwide is difficult to approach, available data indicate that persons with disabilities are among the most marginalized groups in the world (World Health Organization, 2013) and that they have poorer employment outcomes than those without disabilities (Gottliebet.al., 2010) despite the various international initiatives that aimed at empowering them and boosting their employability in different work settings.

Central to this, several scholars (Harcourt et al., 2005; DEOC, 2009; Towalski, 2009) have contributed to the knowledge on the reasons behind the decreased employability of people with disabilities despite the frequentlyreported benefits of employing disabled persons (ref). In tourism however, most of the research that has been carried out in this particular area - to date reflects experiences derived from the western workplaces and mainly in the hospitality sector whereas, almost no information reflecting the employability of the disabled in travel agencies was found available in the literature whether nationally or internationally. In an attempt to fill in the aforementioned gap in the existing body of knowledge on the employment of persons with disabilities in the travel business, the current paper aims at: (1) Identifying the areas in which persons with mobility disabilities could be employed in travel agencies from the travel agents' perspectives; (2) Exploring the key barriers to the employment of persons with mobility disabilities in travel agencies as perceived by travel agents; (3) Investigating the potential means of encouraging travel agencies to employ persons with mobility disabilities; (4) Identifying the potential means of overcoming the barriers that hinder the employability of persons with mobility disabilities in travel agencies from the travel agents' opinion; (5) Assessing the effect of barriers confronting travel agents in employing persons with mobility 
disabilities and the extent to which these barriers influence the travel agents' future intentions; (6) Detecting the significant differences between large and small travel agents in terms of overcoming the barriers and future intentions; (7) Proposing solutions to overcome the barriers facing travel agents in employing persons with mobility disabilities.

\section{Literature Review}

\section{Disabilities and tourism: conceptual issues}

Disability is an umbrella term and a complex phenomenon that reflects the interaction between features of a person's body and features of the society in which he/she lives. According to the World Health Organization (2016), disabilities may be classified into three main types/categories: impairments (problems in body functions or structure), activity limitations (difficulties encountered by individuals in executing particular tasks or actions), and participation restrictions (problems experienced by individuals in involvement in life situations).

Central to the concept of disability, several studies (Barton \& Oliver, 1997; Albrecht, et al., 2001;Davis, 2006) have contributed to the understanding of the context, representation and integration of the disabled in various aspects of life including tourism. In this respect, the relationship between disability and tourism has been discussed from various standpoints. Some studies (Haulot, 1981; Shaw \& Coles, 2004; Pagán, 2012) have analyzed the disability/tourism relationship within the broader literature on "social tourism" where the inclusion of groups in society who are economically weak or otherwise disadvantaged in tourism participation is the main objective, while others (Buhalis \& Darcy, 2011; Buhalis, et al., 2012) have advocated the notion of "accessible tourism" with the main objective of overcoming accessibility barriers as the major determinant that can affect the travel incentive and experience of persons with disabilities through involving collaborative processes between stakeholders that enable people with access requirements, to function independently and with equity and dignity through the delivery of universally designed tourism products, services and environments. A third group of tourism scholars and researchers (e.g. Cole \& Morgan, 2010; Lee-Ross \& Pryce, 2010) have referred to the relationship between disability and tourism as an equal opportunity issue where the rights of the disabled to participate in the tourism workplace are advocated and the barriers to their inclusion in this domain are investigated and highlighted. 


\section{Employing Persons with Mobility Disability in Travel Agencies: An Exploratory Study Applied to Egyptian Travel Agencies}

\section{Employment of persons with disabilities}

Persons with disabilities have poorer health outcomes, lower educational achievements, less economic participation and higher rates of poverty than people without disabilities (World Health Organization, 2013). Since disability has come to be perceived as a human rights issue (International Labor Organization, 2009; World Health Organization, 2013), several calls have advocated the elimination of discrimination against the disabled populations in the global arena (International Labor Organization, 2009; World Health Organization, 2013) .This has consequently resulted in the introduction of the United Nations Convention on the Rights of Persons with Disabilities (CRPD), the first human rights treaty of the $21^{\text {st }}$ century and the first international treaty to address, build and strengthen the rights of persons with disabilities on a global scale (United States International Council on Disabilities, 2015). According to this convention, the right of persons with disabilities to work on an equal basis with others in a labor market and work environment that is open, inclusive and accessible has been recognized and all forms of employment discrimination against the disabled has been prohibited.

In this respect, records of the United Nations Department of Public Information indicated that in developing countries about 80 to 90 percent of persons with disabilities of working age are unemployed, whereas in industrialized countries the figure varies between 50 to 70 percent. In most developed countries however, the official unemployment rate for persons with disabilities of working age is at least twice that for those who have no disability (UNDPI, 2007a).

\section{Barriers to employment of persons with disabilities in the workplace}

Central to the concept of employment discrimination, several studies have contributed to our understanding of the reasons behind the decreased employability of persons with disabilities in different contexts, despite the frequently-reported employment benefits (i.e. greater creativity, motivation and loyalty, etc.) of hiring persons with disabilities. In Poland for instance, Towalski (2009) explained that the employment of persons with disabilities is hindered by two groups of factors: Barriers on the part of employers (i.e. the high payroll costs, especially in the open labor market), the prevailing view that employees with disabilities are inherently less productive, and the expectations of frequent absences from work on health grounds) and barriers 
on the part of persons with disabilities, such as the economical passivity among those who are unemployed on the basis of their illness or disability, pensioner status, remaining in education and further education and family and household duties. In India, a report prepared by DEOC (2009) indicated that there are several barriers to employment for persons with disabilities, ranging from the inaccessible physical environment, the lack of educational facilities (i.e. sign language interpreters in colleges, suitable hostel accommodation, Braille texts, etc.), the lack of skilled manpower and the attitudes and mindsets of employers.

In the United States of America, a study conducted by the Bureau of Labor Statistics (BLS, 2013)identified the lack of education or training, the lack of transportation, the need for special features at the job, and a person's own disability as barriers to the employment of persons with disabilities in the workplace. Other identified barriers also include: the perception, fear, myth and prejudice that continue to limit understanding and acceptance of disability in workplaces either because they are believed to be unable to work on one hand or because accommodating a person with a disability in the workplace is believed to be a burden for employers on the other hand (UNDPI, 2007b). Institutional barriers were also identified by Harcourt et al. (2005) where an organization may ignore candidates with a disability reflecting the general perspective or approach of the institution. Alternatively, barriers may manifest in the form of organizational practices that marginalize those with disabilities (Harcourt et al., 2005; Johnstone, 2005; Robert \& Harlan 2006; Stone-Romero et al., 2006)

\section{Benefits of employing persons with disabilities}

The benefits of hiring persons with disabilities have also been researched in different contexts. One of the first studies to examine the economic benefits of workers with disabilities in the general workforce of three business sectors (healthcare, retail, and hospitality) in the United States was the Economic Impact study which concluded that workers with disabilities were found to be hardworking, reliable, and not costly in terms of accommodation. They stayed on the job longer, had lower absenteeism rates, and had an equivalent number of worker's compensation claims when compared to participants without disabilities (Hernandez and McDonald, 2007).

Schneider and Dutton (2002) further referred to higher loyalty and better performance as some of the advantages of hiring workers with disabilities. Similarly, Hernandez et al. (2008) referred to the numerous benefits of hiring persons with disabilities including low absenteeism rates, long tenures, 


\section{Employing Persons with Mobility Disability in Travel Agencies: An Exploratory Study Applied to Egyptian Travel Agencies}

loyalty, reliability, and hardworking. The cost of accommodating workers with disabilities was also found to be minimal. Despite the prevailing managerial perception of high accommodation costs for persons with disabilities in the workplace. Several earlier studies (Oshkosh Area Workforce Development Center, 2007; Blanck, 1996; DuPont, 1993) have also referred to the benefits of employees with disabilities in terms of productivity, reliability, and attendance. Nevertheless, although the benefits were found to be considerable and the employment of persons with disabilities was widely seen as beneficial for the business environment in terms of its positive impact on staff and morale (Goldstone \& Meager, 2002), the employment rate for persons with disabilities remained low in the various work settings. This gap suggests the pressing need to educate the business community about the benefits of having a disabled workforce, and how these benefits may outweigh perceived costs (Hernandez et al., 2008)

\section{Means of boosting the employment of persons with disabilities in the workplace}

Several studies have contributed to our understanding of the means of enhancing the employment of persons with disabilities in different work contexts. In the United Kingdom, for instance, it has been indicated that support should be given to the disabled in finding job opportunities on the one hand and to employers in employing persons with disabilities on the other hand. In this respect five areas providing persons with disabilities with effective early support and guidance to overcome barriers to work; improving the skills and access to in-work support required to enhance the employability of persons with disabilities; making the employment of persons with disabilities less risky and less complicated; improving employer's attitudes towards persons with disabilities and building information networks to bring together and disseminate important information to people with disabilities, their employers, friends and family members (Prime Minister's Strategy Unit, 2005). More recently however, three types of practices have been identified that illustrate the attention to disability inclusion in business activities. These include practices related to employers or companies' internal operations (i.e. policy statements, benchmarking activities, employee-disability networks, disability awareness training for management and co-workers, etc.), practices to promote the training, hiring or retention of persons with disabilities and boost their productivity in the workplace (i.e. recruitment or community outreach techniques and programs; internships and training, mentoring and leadership 
programs addressed mainly to those with disabilities; reasonable accommodations to meet the needs of persons with disabilities, policies and practices for business-to-business relationships with entrepreneurs with disabilities, etc.) and practices to collaborate with others to realize disability inclusion in the workplace (i.e. employee volunteer programs; collaboration with unions, NGOs and governments; adherence to accessibility standards and active promotion of such standards; etc.) (International Labor Organization, 2010).

\section{Employment of persons with disabilities in tourism, hospitality and leisure}

Tourism, hospitality and leisure include a wide range of employment areas that are predominantly routine in their technical demand and where the lack of skills provides opportunities for those who might otherwise find regular employment difficult to achieve. In this respect, the tourism and hospitality sector is described as one of the sectors that offers opportunities to members of society across much of its ability and disability range. It can accommodate the actions and abilities of those with exceptional talents as well as the majority of most communities, which may include those who face challenges of a different sort in terms of physical or intellectual ability (Baum, 2006).

Central to this, the majority of literature has placed specific significance on the recruitment and hiring of persons with disabilities in the hospitality and leisure domains where the active recruitment of individuals with disabilities was believed to be extremely important in creating a diverse workforce. Moreover, the role of employment agencies in providing valuable services to companies seeking to recruit persons with disabilities was significantly identified. Including disabilities in corporate diversity plans was also identified as an important aspect in making recruiting persons with disabilities a top-down commitment within an organization (Donelly and Joesef, 2012). In the same context, Paez and Arendet (2014) explained that employing persons with disabilities appears to offer benefits to both employees and employers where employers create a more diverse workforce and gain loyal employees, employees perceive the managers' attitudes towards their disabled counterparts as an opportunity for flexible employment. They further explained that the hospitality industry should be considered an industry with viable employment opportunities for persons with disabilities because hotels and restaurants often look for part-time employees, thus, hospitality work schedules facilitate the incorporation of employees with disabilities, providing for an arrangement beneficial for employee and employer. 


\section{Employing Persons with Mobility Disability in Travel Agencies: An Exploratory Study Applied to Egyptian Travel Agencies}

The high cost of training and accommodating any particular needs of persons with disabilities in the workplace, their limited cross-functional or multitasking skills, their potential mobility that could have a negative impact on night and shift works and the hotel industry's preference for employees with aesthetic and self-presentation are considered key barriers for employing persons with disabilities in hospitality industry (Gröschl, 2011; Nickson et al., 2005). However, the hospitality industry provides a unique set of hiring challenges which include the nature of work, accommodation costs, physical appearance, multi-tasking, part-time work (Donelly and Joesef, 2012). However, Gröschl (2013) found little support for such negative judgments as employees with disabilities - according to his study- were found to be loyal, reliable, and, on balance, require moderate accommodations. The study further indicated that many disabilities had no significant effect on the mobility or shift work of employees. Moreover, the processes of accommodating and training persons with disabilities were found to be frequently associated with minimal costs. Additionally, the physical attributes of persons with disabilities had no negative influence on the experiences of guests. Besides, the findings indicated that developing an organizational climate of openness and tolerance, placing employees with disabilities at the centre of managerial planning and operational processes, and investing in good human resources management practices were essential elements for the integration of persons with disabilities in the workplace.

\section{Research methodology}

Measurements

To achieve the study objectives, a preliminary list of measurement items was originally developed. These items were based on in-depth review of relevant literature pertaining to employing persons with disabilities in tourism and travel industry (Nickson et al., 2005; Baum, 2006; Gröschl, 2007; Joesef \& Donelly, 2012; Gröschl, 2013; Paez \& Arendet, 2014). In an attempt to refine the designed scale, the following steps were conducted: first, four academic experts in disability studies were asked to verify the content validity of the preliminary generated items. Second, five tourism experts were requested to indicate if any of these measurement items needed to be refined. Third, a pretest was conducted with 12 Egyptian travel agents. After the travel agents have qualified each item's face validity, the 30 items of the measurement scale developed for travel agents were all representatives of the constructs of interest. All items were measured on a 5-point Likert scale ranging from strongly disagree (1) to strongly agree (5). The survey was developed to 
measure the perception of Egyptian travel agents towards employing persons with mobility disabilities in travel agencies. In this respect, the survey intended to measure the following four constructs:

- The areas in which persons with mobility disabilities could be employed in a travel agency. In this construct, the following work domains were considered: Planning and organization of tourism programs, leading and guiding tourists, reservation and ticketing, customer service, marketing and sales, human resources, public relations, information technology, administration and secretary, working in transportation or movement departments, working as an accountant, working as a receptionist, communicating with overseas agents electronically.

- The barriers of recruiting persons with mobility disabilities in travel agencies which include the following four items: cost barriers; negative perceptions; mindsets and attitudes of employers; negative attitudes of colleagues and customers (Stone, 1999; Harcourt et al., 2005; Nickson et al., 2005; Baum, 2006; Robert \& Harlan, 2006; UNDPIa, 2007; Towalski, 2009; DEOC, 2009; BLS, 2013).

- Means of encouraging the recruitment of persons with mobility disabilities. This construct encompasses the following five items: raising owners' awareness; tax exemption and other merits; national assistance in cost of social insurance for a person with disability; national assistance in the cost of medical insurance for a person with disability; flexible work hours for the disabled (Donelly and Joesef, 2012).

- Means of overcoming the barriers of recruiting persons with mobility disabilities in travel agencies. This construct consists of the following five items: specialized education and training programs; employment forums; communication with civil society associations; advertisements; recruitment companies (Prime Minister's Strategy Unit, 2005).

One more item was generated to measure travel agent's future intention: "we will employ qualified persons with mobility disabilities in the future", while questions related to demographic profile of respondents made the last part of both surveys.

\section{Data collection}

The current study conducted a series of self-administered surveys over a period of four months (March 2015 to June 2015) using a convenient sample of Egyptian travel agents. A brief description of the study was provided in the cover letter of the survey. The questionnaires were delivered to the travel agents in person. The average time to collect questionnaires from agents was 


\section{Employing Persons with Mobility Disability in Travel Agencies: An Exploratory Study Applied to Egyptian Travel Agencies}

7 days. Phone calls and e-mail messages were used to follow-up. The completed questionnaires were collected either by mail or in person. A total of 300 questionnaires were distributed and 230 were returned. After invalid questionnaires were overlooked such as those with a high percent of incomplete answers or missing important questions, 206 responses were usable for analysis, resulting in a valid response rate of $68.6 \%$.

\section{Data analysis}

In an attempt to explore the perception of travel agents towards the recruitment of persons with mobility disabilities in travel agencies, three statistical tools in three consecutive stages have been implemented: descriptive analysis; multiple regression analysis; t-test analysis. The first stage, focused on the investigation of the respondents' perceptions regarding the areas in which persons with mobility disabilities could be employed in a travel agency, the barriers of recruiting persons with disabilities in travel agencies as well as the means of overcoming such barriers, and the means of encouraging the employability of persons with mobility disabilities in travel agencies. In the second stage, a multiple regression analysis was implemented in order to model the extent to which the identified barriers of recruiting persons with mobility disabilities in travel agencies predict the travel agents' future intentions. The third stage, examined whether any significant differences exist between large and small travel agents in terms of overcoming barriers of recruiting persons with mobility disabilities in travel agencies and their future intensions in this respect. The outcome of this final stage gives an important indication of whether company size has an effect on perceiving different solutions to overcome barriers and future intentions of travel agents.

\section{Results}

\section{Perception of travel agents towards recruiting persons with mobility} disabilities in travel agencies: Descriptive statistics

This stage explores the perception of travel agents towards recruiting persons with mobility disabilities in travel agencies. The internal consistency and reliability of the scale measuring travel agents perception of employing persons with mobility disabilities was evaluated using Cronbach's alpha coefficients. Reliability tests are used to verify how the set of indicators hypothesized for each construct belong together (Nunnally, 1978). The reliability value of each construct is above a value of 0.70 , which is considered acceptable values according to (DeVellis, 2003). 
Concerning the demographic profile of respondents, results indicate that $31.3 \%$ of agencies have fewer than 20 employees while $68.7 \%$ of agencies have more than 20 employees. $90.3 \%$ of travel agents have a published and written policy for recruitment while $9.7 \%$ of travel agencies do not have such a policy. $91.3 \%$ of agencies do not have a recruitment policy that involves items for recruiting persons with mobility disabilities and $8.7 \%$ of agencies have a policy that involves items for recruiting persons with mobility disabilities. $97.1 \%$ of travel agencies do not have currently employees with mobility disabilities while $2.9 \%$ of agencies do have currently an employee with mobility disability. $63.1 \%$ of agents stated that they had previously an employee with disability and $71.8 \%$ of travel agents mentioned that they keen to retain employees after being disabled.

Prior to presenting results of Multiple Regression Analysis and Independent tTest, the researchers present descriptive statistics (means and SDs) of the four constructs with their 30 items that have been used in the questionnaire (table 1). Results show the respondents' perception of different dimensions related to employing persons with mobility disabilities in travel agencies; areas in which persons with mobility disabilities can work in the travel agency, perceived barriers, potential means of encouraging travel agents to recruit persons with mobility disabilities and potential means to overcome barriers of recruiting disabled.

Concerning areas in which persons with mobility disabilities can work in the travel agency, findings revealed that the item "Work as customer service employee" has the highest mean score (3.7) followed by "Work as human resources employee" and "Work as ticketing employee" (3.5) and "Work as IT employee" (3.5). On the other hand, results indicate that the item "Work as a tour guide" has the lowest mean score (2.0) followed by the item "Work as a tour leader" (2.1). With regard to perceived barriers to employ persons with mobility disabilities in travel agencies, findings show that "cost barriers" has the highest mean scores (3.18) followed by "negative consideration of consumers to persons with mobility disabilities" (3.13). Respecting potential means of encouraging travel agents to recruit persons with mobility disabilities, results indicate that " tax exemption and other merits" and " country's assistance in cost of medical insurance" have the highest mean scores (4.6).

Concerning potential means to overcome barriers of recruiting persons with mobility disabilities, results reveal that "specialized education and training programs" has the highest mean score (3.68) followed by "advertisements" (3.34). 
Table (1) Descriptive statistics of variables for travel agents' perception of employing persons with mobility disabilities in travel agencies

\begin{tabular}{|c|c|c|c|}
\hline Variables & Mean $^{a}$ & SD & \\
\hline $\begin{array}{l}\text { The areas in which persons with mobility disabilities could be employed } \\
\text { in a travel agency. }\end{array}$ & & & .719 \\
\hline Planning and organization of tourism programs & 3.2 & 1.19 & \\
\hline Leading tours & 2.1 & 1.03 & \\
\hline Guiding tourists & 2.0 & 1.04 & \\
\hline Ticketing and reservation & 3.5 & 1.01 & \\
\hline Customer service & 3.7 & 1.04 & \\
\hline Marketing and sales & 3.0 & 1.14 & \\
\hline Human resources management & 3.6 & .998 & \\
\hline Public relations & 3.4 & .992 & \\
\hline Information technology & 3.5 & 1.02 & \\
\hline Administration and secretary & 3.2 & 1.19 & \\
\hline Movement and logistics & 2.9 & 1.22 & \\
\hline Accounting & 3.4 & 1.10 & \\
\hline Reception & 2.9 & 1.18 & \\
\hline Communicating with overseas agents electronically & 3.6 & 1.03 & \\
\hline Transportation representative & 3.3 & 1.11 & \\
\hline $\begin{array}{l}\text { Barriers of recruiting persons with mobility disabilities in travel } \\
\text { agencies }\end{array}$ & & & .702 \\
\hline Cost barriers & 3.18 & 1.07 & \\
\hline Negative perceptions, mindsets and attitudes of employers & 3.11 & 1.11 & \\
\hline Negative attitudes of customers & 3.13 & 1.09 & \\
\hline Negative attitudes of colleagues & 2.66 & 1.10 & \\
\hline Means of encouraging the recruitment of persons with mobility disabil & & & .788 \\
\hline Through raising owners' areness & 3.11 & 1.14 & \\
\hline Through tax exemption and other merits & 3.46 & 1.09 & \\
\hline National assistance in cost of social insurance for the disabled & 3.45 & 1.03 & \\
\hline National assistance in cost of medical insurance for the disabled & 3.46 & 1.02 & \\
\hline Flexible work hours for the disabled & 3.42 & 1.06 & \\
\hline
\end{tabular}


Table Continues

Means of overcoming the barriers of recruiting persons with mobility

disabilities in travel agencies.

Specialized education and training programs

$3.68 \quad .88$

Employment forums

$3.31 \quad 1.04$

Communication with civil society associations

$3.22 \quad .96$

Advertisements

$3.34 \quad 1.05$

Recruitment companies

$3.22 \quad 1.12$

We intend to recruit qualified persons with mobility disabilities in the

3.24

1.18

near future

${ }^{a}$ Using a five-point scale from strongly disagree (1) to strongly agree (5).

Effects of barriers of recruiting persons with mobility disabilities in travel agencies on future intentions of travel agencies

This stage gives insights on the effect of the identified barriers of recruiting persons with mobility disabilities in travel agencies on the future intentions of travel agencies. In this respect, the multiple regression analysis was performed to measure the independent effect of the 4 items representing barriers of recruiting persons with mobility disabilities in travel agencies on future intentions (Table 2). Underlying assumption of linearity, normality, and variable independence were tested and met. The multiple regression analysis was significant and explained $42.7 \%$ of the variance $(\mathrm{F}=11.184$, $\mathrm{P}<0.05, \mathrm{R}^{2}=0.427$ ). Negative appreciation of employers had the largest standardized beta coefficient at -0.237 meaning for every one point increase in negative appreciation of employers, future intentions decreased by -0.237 $(\mathrm{t}=-2.565, \mathrm{P}<0.05)$. The standardized beta coefficient for cost barriers was significant at $-0.177(\mathrm{t}=-2.565, \mathrm{P}<0.05)$. The other variables did not have a significant effect on future intentions.

Table (2) Regression coefficient (barriers of recruiting persons with mobility disabilities in travel agencies \& future intentions)

Model Structure

Standardized

coefficients

(beta)

\begin{tabular}{|c|c|c|c|c|c|}
\hline $\begin{array}{l}\text { Barriers of recruiting persons with mobility } \\
\text { disabilities in travel agencies \& future intentions }\end{array}$ & & & 0.000 & 0.42 & $\begin{array}{l}11.1 \\
84\end{array}$ \\
\hline Cost barriers & -0.177 & -2.565 & 0.011 & & \\
\hline Negative appreciation of employers & -0.237 & -3.255 & 0.001 & & \\
\hline $\begin{array}{l}\text { Negative consideration of consumers to persons } \\
\text { with mobility disabilities }\end{array}$ & 0.078 & 1.071 & 0.258 & & \\
\hline Negative consideration of their colleagues & 0.107 & 1.561 & 0.120 & & \\
\hline
\end{tabular}


Comparison of perception of recruiting persons with mobility disabilities in travel agencies between large and small travel agents

This stage identifies the differences in the perception of travel agents regarding the means of overcoming barriers of recruiting persons with mobility disabilities in travel agencies and their future intentions in this respect according to the size of their agencies (i.e. large or small agency). An independent t-test was performed on the data set. Table (3) illustrates the comparison between large and small travel agents sample groups' mean scores. There were no significant differences concerning the five items of the overcoming barriers construct. With regard to future intentions of travel agents toward recruiting persons with mobility disabilities in their agencies, there was no significant difference found in this concern as well.

Table (3) Differences in perception of recruiting persons with mobility disabilities in travel agencies between large and small travel agents

Large travel agents

Small travel agents

Overcoming barriers of recruiting disabled in travel agencies

\begin{tabular}{lll}
\hline Specialized education and training programs & 3.7 & 3.6 \\
\hline Employment forums & 3.5 & 3.4 \\
\hline Communication with civil society associations & 3.4 & 3.3 \\
Advertisements & 3.4 & 3.4 \\
Recruitment companies & 3.3 & 3.4
\end{tabular}

\section{Discussion}

Results of the study reveal that travel agents consider that customer service, human resources, ticketing and IT are the most likely areas in which persons with mobility disabilities could work in travel agencies according to travel agents' perspectives. While leading and guiding tours are the least considered 
areas for a disabled person to work in a travel agency; this implies that persons with mobility disabilities could not meet some travel agenciesspecific work requirements. These results are consistent with the findings of Nickson et al. (2005) which revealed that persons with disability are perceived as lacking the required innate capabilities and characteristics that are required for employment in the hotel industry. However, persons with mobility disabilities has no effect on undertaking certain tasks which are closely related to the core work of the travel agency such as working as a ticketing employee. Therefore, this may not has a negative impact on customer experiences.

Consistent with the work of Gröschl (2005) and Houtenville \& Kalargyrou (2012) the current study findings reveal that the key barrier that encounters travel agencies to employ persons with mobility disabilities as conceived by travel agents is cost barrier; it could be argued that these costs might relate to the costs of medical care of persons with disabilities, more intense and longer training sessions that the employees with disabilities might need compared with employees without disabilities. The second key barrier reported in this regard is the negative consideration of customers toward employees with mobility disabilities. Unlike the previous result, it has been found that customers appreciate organizations that employ persons with disabilities particularly at hospitality and catering industry (Siperstein et al., 2005) It could be assumed that the unfamiliarity of travel agencies' customers to deal with employees who are persons with disabilities could be regarded as a barrier. However, developing initiatives to employ persons with disabilities in travel agencies could be a contributor that might change this negative perception towards dealing with employees with mobility disabilities, specifically if the agents pay much concern to certain issues specifically job description and disabled competencies concerns.

Concerning potential means of encouragement as regarded by travel agents to employ persons with mobility disabilities, results indicate that tax exemption and other merits and country's assistance in the cost of medical insurance were found to be the most important means of encouragement. These results are in line with the findings of Houtenville \& Kalargyrou (2012) and Wittmer \& Wilson (2010) that governmental financial assistance which exists in many countries, employer tax credits and incentives are among the policies that could encourage companies to hire employees with disabilities.

For potential means of overcoming barriers to employ persons with mobility disabilities, findings illustrate that specialized education and training 


\section{Employing Persons with Mobility Disability in Travel Agencies: An Exploratory Study Applied to Egyptian Travel Agencies}

programs and advertisements are the most important means to overcome these barriers according to travel agents' point of view. These results are in line with the findings of Gröschl (2005) that better communication, promotion and education are essential factors for generating opportunities to employ persons with disabilities in hotels. In this concern, it might be useful to provide specialized training courses associated with the travel operation processes and other specific-travel industry courses at both tourism educational institutions and specialized centers or on-the-job training to best qualify persons with mobility disabilities. Moreover, providing appropriate and sufficient campaigns to advertise such courses could be of great importance.

It is expected that the Egyptian Constitution 2014 will lead to increased initiatives to hire persons with disabilities in different sectors. According to Article number 81 of the Egyptian Constitution 2014, the State should provide persons with disabilities with job opportunities and allocate a percentage of job opportunities to them. In this concern it worth to mention that there were a few initiatives that were taken in the Egyptian tourism and hospitality sector in 2014 concerning hiring persons with disabilities in hotels which took a social responsibility viewpoint in employing competent persons with disabilities.

When assessing the potential effect of the barriers that travel agents might face to hire persons with mobility disabilities on agents' future intention, the study indicates that negative appreciation of employers is considered the main barrier that negatively affects the future intentions of travel agents to employ persons with mobility disabilities. In this concern, (Gröschl, 2007, p.683) indicated in his findings that "employers' stereotypes and perceptions of performance traits characterizing persons with disabilities "are among those barriers and challenges that influence providing employment opportunities for disabled persons". Cost barriers were found as well to be the second key barrier that has a significant negative impact on their future intentions.

Built on previous research (Bruyère et al., 2006; Houtenville \& Kalargyrou, 2012) which claimed that company size had a considerable impact on employment concerns and workforce needs and research that compare different perspectives of employing persons with disabilities between large and small companies and their findings which reveal that smaller hospitality 
companies were less likely to employ persons with disabilities compared with larger companies as this might due to a financial concern, the current study aims to investigate significant differences between large and small travel agents in perceiving potential means of overcoming different barriers to employ persons with mobility disabilities; no significant differences were reported between large and small travel agencies in this concern. These findings are consistent with the results of Bruyère et al. (2006) in which they confirmed that large and small companies have nearly the same perceptions concerning addressing barriers within their organizations. Not surprisingly, the study results do not report significant differences as well between the two groups concerning their future intentions to hire qualified persons with mobility disabilities. This might indicate that those agents do consider their social responsibility and providing equal employment opportunities to persons with mobility disabilities as well as to persons without disabilities.

\section{Conclusion}

Despite the growing number of studies that address the issue of employment and disability and benefits of employing persons with disabilities such as loyalty, dedication, reliability, hard work, co-operation, productivity and motivation (Gröschl, 2005; 2007), employment of persons with disabilities has not been studied in the context of travel industry. Compared with very few previous studies which focused on employing persons with disabilities in the hospitality industry (e.g. Nickson et al., 2005; Baum, 2006; Gröschl, 2007; Gröschl, 2011; Donelly \& Joesef, 2012; Gröschl,2013; Paez \& Arendet, 2015) the present study is considered the first that investigates the perception of travel agents towards employing persons with mobility disabilities in travel agencies.

One of the most important theoretical contributions of the present study lies in integrating different uniqueness structures related to hiring persons with mobility disabilities in the travel industry to understand the relative importance of employing persons with disabilities in the retail travel environment. This research generates insights for managers to understand the most salient aspects of hiring persons with mobility disabilities in travel agencies to address benefits and barriers related to employment of persons with mobility disabilities.

By understanding how travel agents conceive different dimensions concerning employing persons with mobility disabilities, managers can carry out necessary adjustments to meet their social responsibilities and provide equal employment opportunities, and provide programs that support the 


\section{Employing Persons with Mobility Disability in Travel Agencies: An Exploratory Study Applied to Egyptian Travel Agencies}

integration of persons with disabilities in their workforces; for example managers should identify each job requirements and decide if the person with a disability has the required competencies that qualify this person to undertake his job appropriately. Therefore, employers will guarantee future job performance and customer satisfaction.

The proposed measures for understanding travel agents' perceptions towards employing persons with mobility disabilities can provide a practical tool for managers to assess key areas, main barriers, means of encouragement and potential means to overcome barriers according to agents' points of view.

This study is unique in identifying key barriers related to hiring persons with mobility disabilities that affect travel agents' future intentions as regarded by travel agents. The study investigates as well significant differences that could be found between large and small travel agencies according to their perception of means of overcoming barriers of employing persons with mobility disabilities.

\section{Limitations and future research}

The present study provides a comprehensive understanding of different aspects related to employing persons with mobility disabilities. However, it has several limitations that need to be addressed. First, despite the similarities in the job of travel agencies and the characteristics of persons with mobility disabilities that could allow for a number of recommendations to be applied to other travel agencies in different markets, the data were collected from Egypt only; therefore, generalizing the study results to other travel agents in different countries may be inappropriate. Second, the questionnaire used a convenience sampling method, which put another limitation to generalize the results of the current study. The samples size is relatively small, future research should consider using larger sample to be able to generalize results to a broader context. With time, the barriers construct examined in this research requires further investigation to assess emerging barriers with the increased initiatives taken to integrate persons with disabilities in the workforce

Obviously, more comparative studies among travel agents within different countries with different perspectives regarding employing persons with disabilities in the travel market could produce interesting results. The current study focused on persons with mobility disabilities, future research should 
consider employment of persons with different types of disabilities and the effect they have on the travel agents' performance.

\section{References}

Albrecht, G., Seelman, K. and Bury, M. (2001). eds. Handbook of Disability Studies, Sage Publications, Inc., USA.

Barton, L. and Oliver, M. (1997). eds. Disability Studies: Past, Present and Future, The Disability Press, Leeds, UK.

Baum, T. (2006). Human Resource Management for Tourism, Hospitality and Leisure: An International Perspective, Thomson Learning, United Kigdom

Blanck, P. (1996). Communicating the Americans with Disabilities Act, transcending compliance: 1996 follow-up report on Sears, Roebuck and Co. Iowa City: The Annenberg Washington Program in Communications Policy Studies of Northwestern University.

BLS (2013). Persons with a Disability: Barriers to Employment, Types of Assistance, and other Labor-Related Issues, Bureau of Labor Statistics, US Department of Labour, News Release, May 2012, URL:http://www.bls.gov/news.release/archives/dissup 04242013.pdf . Accessed on: 6 January 2016

Bruyère, S., Erickson, W., and VanLooy, S. (2006). The impact of business size on employer ADA response. Rehabilitation Counseling Bulletin 49:194206.

Buhalis, D. and Darcy, S. (2011). eds. Accessible Tourism: Concepts and Issues, Channel View Publications, Bristol.

Buhalis, D., Darcy, S. and Ambrose, I. (2012). Best Practice in Accessible Tourism, Channel View Publications, Bristol.

Cole, S. and Morgan, N. (2010) eds. Tourism and Inequality: Problems and Prospects, CAB International, UK. 


\section{Employing Persons with Mobility Disability in Travel Agencies: An Exploratory Study Applied to Egyptian Travel Agencies}

Davis, L. (2006) eds. The Disability Studies Reader, $2^{\text {nd }}$ edition, Routledge: Taylor and Francis Group, USA.

DEOC (2009). Employment of Disabled People in India, Base Line Report February 2009, Diversity and Equal Opportunity Centre, URL: file:///Users/macbookpro/Downloads/Employment\%20of\%20disabled\%20pe ople\%20in\%20India.pdf Accessed on: 10 January 2016.

DeVellis, R.F. (2003). Scale development: Theory and applications, $2^{\text {nd }}$ ed. Thousand Oaks, California: Sage.

Donelly, K. and Joesef, J. (2012). Disability Employment in the Hospitality Industry: Human Resourse Considerations, Cornel HR Review, Cornel University ILR School, URL:

http://digitalcommons.ilr.cornell.edu/cgi/viewcontent.cgi?article=1032\&con text=chrr Accessed on: 02 January 2017.

DuPont de Nemours and Company (1993). Equal to the task II: 1990 DuPont survey of employment of people with disabilities. Wilmington: DuPont de Nemours and Company.

Goldstone, C. and Meager, N. (2002). Barriers to Employment for Disabled People, In-house report 95, NOP Consumer and Institute for Employment Studies on behalf of Department of Work and Pensions, Crown copyright, HerMajysty's Stationary Office, London, URL:

http://www.disability.co.uk/sites/default/files/resources/Barriers $\% 20$ to $\% 20 \mathrm{E}$ mployment.pdf Accessed on: 10 February 2017.

Gottlieb, A., Myhill, W. and Blanck, P. (2010), Employment of People with Disabilities, Center for International Rehabilitation Research Information and Exchange (CIRRIE), URL:

http://cirrie.buffalo.edu/encyclopedia/en/pdf/employment_of people_with_di sabilities.pdf accessed on 2 Feb. 2017.

Gröschl, S. (2005). Persons with Disabilities: A Source of Non-traditional Labour for Canada's Hotel Industry, Cornell Hotel and Restaurant Administration Quarterly, 42 (2): 258-275. 
Gröschl, S. (2007). An exploration of HR policies and practices affecting the integration of persons with disabilities in the hotel industry in major Canadian tourism destinations. International Journal of Hospitality Management, 26: 666-686.

Gröschl, S. (2011). Barriers for Persons with Disabilities in the Hotel Industry: A Reality Check, Amherst International CHRIE Conference-Refereed Track, 2011 ICHRIE Conference, Jul.28, University of Massachusetts - Amherst ScholarWorks@UMass Amherst, URL: http://scholarworks.umass.edu/cgi/viewcontent.cgi?article=1578\&context=re fereed, Accessed on 5 January 2016.

Gröschl, S. (2013). Presumed Incapable: Exploring the Validity of Negative Judgments about Persons with Disabilities and Their Employability in Hotel Operations, Cornell Hospitality Quarterly, 54 (2): 114-123.

Harcourt, M.; Lam, H.; and Harcourt, S. (2005). Discriminatory Practices in hiring: institutional and rational economic perspectives, International Journal of Human Resource Management, 16 (11): 20113-32.

Haulot, A. (1981). Social tourism: Current dimensions and future developments, International Journal of Tourism Management, 2(3): 207-212.

Hernandez, B. and McDonald, K. (2007) Exploring the Bottom Line: Exploring the Costs and Benefits of Workers with Disabilities, The Economic Impact Study, Depaul University, Illinois Department of Commerce and Economic Opportunity, URL: http://bbi.syr.edu/ assets/staff bio publications/McDonald Exploring the B ottom_Line_2007.pdf Accessed on: 12 October 2015.

Hernandez, B., McDonald, K.., Divilbiss, M., Horin, E., Velcoff, J. and Donoso, O.(2008) Reflections from Employers on the Disabled Workforce: Focus Groups with Healthcare, Hospitality and Retail Administrators, Employee Responsibilities and Rights Journal, 20(3): 157-164.

Houtenville, A. and Kalargyrou, V. (2012). People with Disabilities: Employers' Perspectives on Recruitment, Practices, Strategies, and Challenges in Leisure and Hospitality, Cornell Hospitality Quarterly 53(1):40-52. 


\section{Employing Persons with Mobility Disability in Travel Agencies: An Exploratory Study Applied to Egyptian Travel Agencies}

International Labour Office (2011) Achieving Equal Employment Opportunities for People with Disabilities Through Legislation: Guidelines, An Education and Training Guide, Irish Guide.

International Labor Organization (2009) International Labour Organization, Promoting the Employability and Employment of People with Disabilities through Effective Legislation (PEPDEL) URL:

http://www.ilo.org/wcmsp5/groups/public/---ed_emp/--ifp skills/documents/publication/wcms 111458.pdf Accessed on 2 Jan. 2017.

International Labour Organization (2010) Disability in the Workplace: Company Practices, Working Paper No.3, Bureau for Employers' Activities and Skills and Employability Department, URL:

http://www.businessanddisability.org/images/pdf/disability_workplace.pdf Accessed on 8 Feb. 2017.

International Labour Organization (2016) Disability and Work, URL: http://www.ilo.org/global/topics/disability-and-work/WCMS 475650/lang-en/index.htm Accessed on: 27 January 2015.

Johnstone, J. (2005) Employment of Disabled Persons in the Academic Library Environment, Australian Library Journal, 54 (2): 156-163.

Lee-Ross, D. and Pryce, J. (2010) Human Resources and Tourism: Skills, Culture and Industry, Aspects of Tourism Texts, Channel View Publications, Bristol.

Nickson, D., Warhurst, C. and Dutton, E. (2005). The importance of attitude and appearance in the service encounter in retail and ho spitality, Managing Service Quality, 15 (2): 195-208.

Nunnally, J. (1978). Psychometric theory, $1^{\text {st }}$ ed. New York: McGraw-Hill.

Oshkosh Area Workforce Development Center (2007). Studies related to the employment of individuals with disabilities, (1948-2000). Oshkosh: Oshkosh Area Workforce Development Center [Electronic version] (May 22). 
Paez, P. and Arendet, S. (2014). Managers' Attitudes Towards Employees with Disabilities in the Hospitality Industry, International Journal of Hospitality and Tourism Administration, 15(2): 172-190.

Pagán, R. (2012).Time allocation in tourism for people with disabilities, Annals of Tourism Research, 39 (3): 1514-1537.

Prime Minister's Strategy Unit (2005). Improving the life chances of disabled people, URL:

http://www.disability.co.uk/sites/default/files/resources/Improving\%20Life $\%$ 20Chances.pdf Accessed on: 20 March 2016.

Robert, P. and Harlan, S. (2006). Mechanisms of Disability Discrimination in Large Bureaucratic Organizations: Ascriptive Inequalities in the Workplace, The Sociological Quarterly, 47 (4): 599-630.

Ryerson University (2016). What is disability studies? School of Disability Studies, Ryerson University, Ontario, Canada, URL:

http://www.ryerson.ca/disabilitystudies/ Accessed on: 16 January 2016.

Schneider, J. \& Dutton, J. (2002). Attitudes towards disabled staff and the effect of the national minimum wage: a delphi survey of employers and disability employment advisors, Disability \& Society, 17: 283-306.

SDS (2016). What is Disability Studies? Society for disability studies, University at Buffalo, URL: http://www.disstudies.org/about/what_is_ds Accessed on: 15 March 2016.

Shaw, G. \& Coles, T. (2004). Disability, holiday making and the tourism industry in the UK: a preliminary survey, Tourism Management, 25 (3): 97420.

Siperstein, G., N. Romano, A. Mohler, and R. Parker. (2005). A national survey of consumer attitudes towards companies that hire people with disabilities. Journal of Vocational Rehabilitation (24): 3-9.

Stone, E. (ed.) (1999). Disability and Development: Learning from action and research on disability in the majority world, Leeds: The Disability Press, pp.1-18. 


\section{Employing Persons with Mobility Disability in Travel Agencies: An Exploratory Study Applied to Egyptian Travel Agencies}

Stone- Romero, E., Stone, D. and Lukaszewski, K. (2006). The Influence of Disability on Role-Taking in Organizations, in Konard, A., Prasad, P. and Pringle, J. (ed), Handbook of Workplace Diversity, Sage Publications, pp. 402-431.

Towalski, R. (2009). Barriers to the Employment of Disabled Persons, The European Foundation for the Improvement of Living and Working Conditions (Eurofound), URL:

http://www.eurofound.europa.eu/observatories/eurwork/articles/other/barriers -to-the-employment-of-disabled-persons Accessed on: 11 March 2016.

UIC (2015). Why disability studies? Department of Disability and Human Development, University of Illinois, URL:

http://ahs.uic.edu/dhd/academics/phd Accessed on:11 March 2016.

UNDPI (2007a). Disability and Employment, Employment of Persons with Disabilities, Fact sheet 1, United Nations Department of Public Information — DPI/2486 - November 2007. URL:

http://www.un.org/disabilities/default.asp?id=255. Accessed on11 March 2016.

UNDPI (2007b). Employing persons with disabilities: Fears and Realities, United Nations Department of Public Information Fact sheet 2- DPI/2486November 2007, URL:

http://www.un.org/disabilities/documents/toolaction/employmentfs.pdf. Accessed on: 20 January 2016.

United Nations Educational, Scientific and Cultural Organization (2013). UNESCO Global Report: Opening New Avenues for Empowerment ICTs to Access Information and Knowledge for Persons with Disabilities, URL: http://www.who.int/disabilities/world_report/2011/chapter8.pdf. Accessed on: 18 April 2015

United States International Council on Disabilities (2015). The Convention on the Rights of Persons with Disabilities, URL:

http://www.usicd.org/index.cfm/convention. Accessed on: 20 April 2015. 
World Health Organization (2013). Ten facts on disability, URL:

http://www.who.int/features/factfiles/disability/en/ Accessed on: 11 January 2017.

World Health Organization (2016). Disabilities, World Health Organization, URL: http://www.who.int/topics/disabilities/en/ Accessed on 11 January 2017.

Wittmer J. and Wilson L. (2010). Turning Diversity into \$: A Business Case for Hiring People with Disabilities. Association of Talent Development, February: 58-61 https://www.td.org/.../2010/.../Turning-Diversity-IntoDollars-a-Busi... Accessed on 20 March 2015. 